\title{
Readiness for Change: The Influence of MIL on Hospital Workers During Pandemic
}

\author{
Sri Wahyuni ${ }^{1 *}$, Nurmuliasneny Musa ${ }^{2}$, Suryadi Tandiayuk ${ }^{3}$ \\ ${ }^{I}$ Department of Psychology, Faculty of Medicine, Hasanuddin University Makasssar, Indonesia \\ ${ }^{2}$ Department of Psychology, Faculty of Medicine, Hasanuddin University Makassar, Indonesia \\ ${ }^{3}$ Department of Psychology, Faculty of Medicine, Hasanuddin University Makassar, Indonesia \\ *Corresponding author.Email: s.wahyuni@unhas.ac.id
}

\begin{abstract}
This study aims to determine the influence of margin in life (MIL) on readiness for change in hospital workers during the Covid-19 pandemic. This pandemic has significant impacts on all aspects of human life, which produce a process of changes in the organization. Each individual has a different experience, but every health worker may be unprepared to deal with this pandemic, mainly since this pandemic has caused social disorganization in all aspects of life. Hospitals are one of the organizations most affected by this pandemic, so readiness for change is needed for the organization's ability to optimally deal with the change process and how the margin in life contributes to the organization's readiness to face accidental changes or unplanned changes. Participants in this study were 212 workers at Rumah Sakit Wahidin Sudirohusodo (RSWS) Makassar. The instrument used to collect data is the readiness for change scale and the MIL scale. The method to test the hypothesis is simple regression. The results of data analysis show the value of R Square $=0.934$, sig. 0.00 . MIL significantly influences readiness for change in hospital workers at RSWS Makassar.
\end{abstract}

Keywords: margin in life, readiness for change, hospital workers

\section{INTRODUCTION}

Changes are a sure phenomenon that will and continue to occur. Whether it was for individuals or organizations will one day experience this natural process and should be able to adapt. Change is also a component in which individuals and groups must try to keep up and try to adapt [1]. According to Arijanto et al., there are five types of change, and one of them is called accidental change. Accidental changes are organizational activity shifts due to external forces beyond control [2].

COVID-19 pandemic is one example of an unexpected change initially triggered by the spread of the Covid-19 virus worldwide. The pandemic has had a significant impact non all aspects of human life, one of which is organizational change. Places like hospitals are one of the most affected by this pandemic. Dr. Wahidin Sudirohusodo General Hospital in Makassar is one of the hospitals for COVID-19 patients with 878 health workers to adapt and develop strategies to deal with these changes [3]. As a result, readiness to face changes in the organization or readiness for change is required.
Holt et al. defined readiness for change, namely readiness to participate in organizational activities. Readiness is defined as a comprehensive attitude that is simultaneously influenced by the content, process, context, and individuals who face these changes [4]. Meanwhile, Aljohni defines readiness for change as a core challenge for professional organization human resource development because every change involves all individuals working in an organization [5]. There are five dimensions in readiness for change: discrepancy, change self-efficacy, organizational valence, management support, and personal valence [4].

One aspect is related to the process of resilience and individual ability to face change, that is margin in life (MIL). McClusk developed the base theory of margin in life, which describes individuals' potential in adulthood [6]. They are loads of unseen burdens, feelings, psychological functions, or concrete tasks and mental processes. Power is a source of energy used to balance the load and is a positive thing because it increases the group's happiness, pleasure, and strength. Margin in life is an essential component for health workers in facing the challenges brought by the COVID-19 pandemic. The aspects of margin 
in life include job demand, organization culture, family, management leadership relations, self, health, job knowledge \& skills, and social relations in the workplace [7], [8].

The result of an initial survey conducted by researchers found that health workers are overwhelmed in the face of change due to ver high spike in patients counts, fear of being infected with the virus, fear of losing someone close to them, worrying about not being able gave maximum service to patients, fear of losing their loved ones or even profession. McClusky explained all these forms of concern as someone grew up; eventually, they will face complexities in their life that requires them to balance between load and power they have to always stay in steady-state [6].

Research conducted by Madsen et al. found a significant correlation between readiness for change and the individual's margin in life [8]. In addition, Hanpacern, in his research, stated that individuals who can increase their margin in life would have more incredible energy to act, have a high level of satisfaction, and can optimally handle all emergencies and changes that occur in their lives [7].

Based on this description, it is essential to examine further how significant the contribution of margin in life is to the readiness for change in health workers, especially during the pandemic. Given that health workers and hospitals are one of the important sectors most affected by this pandemic, the surge in patients that impacts the provision and distribution process of services tests the readiness of this organization to make adjustments or changes effectively and efficiently.

\section{METHOD}

This study used a correlational quantitative research design. Respondents that participated in this study were 212 health workers. The sampling technique used in this study are incidental sampling and the instrument used for data collection is the readiness for change scale from Holt et al., which has been modified by Majid and the margin in life scale from Madsen et al. who have gone through the process of adaptation, validity and reliability testing [9], [8]. Meanwhile, data collection is done online. Then, simple linear regression analysis was used to test the research hypothesis.

\section{RESULT}

Table 1. Descriptive statistics

\begin{tabular}{lcccc}
\hline Variable & Min. & Max. & Mean & SD \\
\hline $\begin{array}{l}\text { Vargin in } \\
\text { LIfe }\end{array}$ & 114 & 190 & 189.23 & 14.904 \\
$\begin{array}{l}\text { Readiness for } \\
\text { Change }\end{array}$ & 107 & 238 & 161.32 & 21.743 \\
\hline
\end{tabular}

Note: $\mathrm{N}=212$ (male $=82$; female $=130)$; Mean $=$ the average value of total score; $\mathrm{SD}=$ standard deviation.

The results in this study indicate that the level of readiness for change of Dr. Wahidin Sudirohusodo General Hospital health workers in facing changes, especially during the COVID-19 pandemic, is in the high category of $26 \%$, so this indicates that Dr. Wahidin Sudirohusodo General Hospital readiness to change is in the high category. In line with the results of the margin in life, which is also in the high category of $21 \%$.

Table 2. Regression analysis

\begin{tabular}{llllll}
\hline \multicolumn{1}{l}{ Variable } & N & R & $\mathbf{R}^{2}$ & Sig \\
\hline $\begin{array}{l}\text { Margin in Life } \\
\text { Readiness for } \\
\text { Change }\end{array}$ & 212 & .967 & .934 & .000 \\
\hline
\end{tabular}

The table above presented the study results using the simple linear regression test. Based on the table, it is known that the correlation index $(\mathrm{R})$ of the margin in life variable with readiness for change is 0.967 and is positively correlated. This means that the higher the margin in life, the higher the readiness for change. Meanwhile, the $\mathrm{R}$ square value is 0.934 and the significance value is 0.00 . This value indicates that the margin in life significantly contributes $93.4 \%$ to readiness for change. 
Table 3. Regression analyses based on MIL Aspects

\begin{tabular}{lcccc}
\hline \multicolumn{1}{c}{$\begin{array}{c}\text { Aspects of } \\
\text { Mul }\end{array}$} & N & R & $\mathbf{R}^{2}$ & Sig \\
\hline $\begin{array}{l}\text { Job demand } \\
\begin{array}{l}\text { Organization } \\
\text { Culture }\end{array}\end{array}$ & 212 & 0.977 & 0.954 & 0.000 \\
$\begin{array}{l}\text { Family } \\
\text { Management }\end{array}$ & 212 & 0.970 & 0.941 & 0.000 \\
$\begin{array}{l}\text { Leadership } \\
\begin{array}{l}\text { Relation } \\
\text { Self }\end{array}\end{array}$ & 212 & 0.961 & 0.924 & 0.000 \\
$\begin{array}{l}\text { Health } \\
\text { Job Knowledge } \\
\text { \& Skills }\end{array}$ & 212 & 0.951 & 0.904 & 0.000 \\
$\begin{array}{l}\text { Social Relation } \\
\text { in the Work }\end{array}$ & 212 & 0.948 & 0.898 & 0.000 \\
Place & 212 & 0.742 & 0.549 & 0.000 \\
\hline
\end{tabular}

The table above shows that the aspect of margin in life that has the most influence is job demand ( $R$ square $=0.954)$, while the aspect that has the least contribution is social relations in the workplace $(\mathrm{R}$ Square $=0.549$ ) .

\section{DISCUSSION}

This study indicates that margin in life significantly contributes to the readiness for change of health workers during the pandemic. Margin in life can be the main booster and contributor in forming organizational readiness to face change. This result is in line with previous research conducted by Hanpachern with the result that margin in life can assist an organization in identifying readiness for change, especially in times of critical change [7]. Margin in life, which consists of work and non-work aspects, has a solid relationship in predicting organizational readiness to change. Organizations that are successful in facing change have high MIL within their members and can balance the load and power.

The contribution value of margin in life in readiness for change is in the high and significant category. This means that the readiness of health workers to face change is also influenced by the margin in life or the potential they have. That potentials were both from within and the potential that comes from the surrounding environment. Madsen et al. in their research suggest that in managing a change in the organization, all parties will face critical challenges that can be described as individual and group burdens, it is essential to improve organizational capabilities in terms of readiness for change and one form of intervention that can improve organizational readiness in facing change is that there is a large margin in life of the group [8].

The result from this study is also in line with the research conducted by Saragih that several individual attributes have a significant impact on readiness for change, one of which is life experience [10]. There are five life experience attributes: spirituality, education, family, community, and work-life. Some of these attributes are an aspect that is part of the margin in life.

An interesting finding in this study is that the highest aspect in influencing readiness for change is job demand $(\mathrm{R}$ square $=0.934)$. Job demand is a condition of workers based on their workload; this refers to physical, psychological, social, or organizational aspects that require ongoing physical and psychological abilities. In comparison, the aspect that contributes the least to readiness for change is the aspect of social relations in the workplace ( $R$ Square $=0.549$ ). Social relations in the workplace are relationships between two or more individuals who can influence each other, change, and improve behavior. This refers to social relationships in the workplace, such as cooperation, emotion, attention, mutual assistance, and understanding co-workers' feelings, both superiors and other co-workers.

These findings are contrasted with research conducted by Hanpachern and Madsen et al. that ideally, organizations need to grow and improve their psychological and social potential in carrying out change and facing challenges in the workplace [7], [8]. One essential aspect is social relations, when workers can foster good social relations and help each other. The research revealed that the support of colleagues would make workers more enthusiastic to carry out their duties and responsibilities rather than relying on written workloads and responsibilities.

This study indicates that the level of margin in life and readiness for change of health workers in the face of change, especially during the COVID-19 pandemic, is in the high category. This is in line with research by Hanpachern and Kalynych that workers who work in the field of public service professions will be more prepared to face changes in the workplace than workers who focus on producing goods/manufacturing departments [7], [11]. This is because professional work such as service to the community can adapt easier to the adaptation process than workers who have to face changes when constructing a product or operating a tool.

Another finding is that the age range that had a high readiness for change score is in the age range of 56-60 years old. This is in line with the research 
proposed by Meriam and Caffarella that suggested margin in life is a potential that adults should have, the understanding that adults are a period in which individuals face growth, change, and integration so that individuals are expected to consistently seek a balance between load and power required [12].

However, this result contrasts with previous studies such as Holt et al. that found productive age in the range of $20-35$ is the age most ready to face organizational changes. This result is different from that found by researchers, where respondents who are more prepared to face change are 56-60, which is the age of late stages of adulthood [4]. Meanwhile, the low category of readiness for change is dominated by respondents aged 31-35 years. Based on the results of the open question asked to respondents aged 56-60, consider the work they do is a pure responsibility to serve the community sincerely so that all forms of change should be carried out optimally. In addition, as a health worker with older age and more experience, it is vital to set an example and be a role model for juniors or new workers to carry out their duties and responsibilities to the maximum.

Based on gender difference results in this study, it was found that the high readiness for change score was more dominated by men than women. This is in line with research conducted by Kalynych that men are more prepared to face change, while women are more likely to leave work responsibilities because they have to take care of the family. This is also because readiness for change is heavily influenced by individual attributes in the form of self-efficacy, self-concept in themselves, rather than being influenced by gender, which is an individual's biological condition [11]

Based on the level of education, it was found that workers with bachelor education level dominated the readiness for change score and the high margin in life, at high readiness for change score of $30 \%$ and a high margin in life score of $38 \%$. These results align with the research conducted by Madsen et al. that the latest education has a significant effect on individual readiness in facing changes in a group and affects the margin in life or potential they have. Madsen et al. revealed that individuals with a high level of education would be more prepared to face change and have a higher margin in life than workers with lower educational status [8]. This is because individuals with higher education tend to have greater selfrestraint, spend a longer time or duration of work, have more complex workloads, and view that their workload is a shared burden as an organization.

Meanwhile, based on the employment status of civil and non-civil workers, it was found that civil workers had a high readiness for change category, which was $28 \%$, and the margin in life variable was $26 \%$ compared to non-civil workers. The results found are in line with research by Hanpachern, which suggests that permanent workers have greater selfrestraint than non-permanent workers. This is due to differences in the experience of individuals who work with permanent and non-permanent work status [7].

This study also found that readiness for change and margin in life were high in married respondents $(23 \%)$. In line with previous research conducted by Kalynych that married individuals have a larger supporting system that can be a power or strength to face all obstacles and changes in their lives. This result is also influenced by the well-being of married people, which will affect their margin in life [11].

The first open question is about the respondents' expectations of the organization in general. The results found that most respondents expect that hospitals can improve their quality, especially in the face of change, provide services expected by the community, and pay attention to the welfare of the workforce, especially honorary workers. This is in line with research conducted by Holt et al. that in facing change, there are at least some things that members of the organization, namely need (a) confidence that they can adapt optimally in the face of change and can show the best performance in dealing with change, (b) believe that the changes faced will provide benefits to individuals and the organization in general, (c) believe that leaders or superiors can be role models in encouraging the creation of change and finally (e) change is something that is needed by individuals in an organization [4].

In the results of the second open question regarding respondents' expectations of themselves, most of the respondents revealed that they could maintain health even amid changes like this, can continue to be enthusiastic, practice, and learn to improve the quality of work, be more adaptive to changes and challenges faced at work, Get support from family and friends. This is in line with the aspects of margin in life, especially in the non-work aspect that self, health, and family contribute to an individual's ability to face critical challenges in life. So that to achieve a high margin in life and contribute to readiness for change, it is essential to pay attention to aspects that can be developed, both in the work and non-work aspects.

\section{CONCLUSION}

Based on the study results, it can be concluded that there is a significant contribution margin in life to the readiness for change of the Dr. Wahidin Sudirohusodo General Hospital health workers 
during the COVID-19 pandemic. The results of this study also indicate that health workers are generally ready to face change and can make adjustments to the changes that occur, and it is hoped that the Makassar RSWS can recognize all types and forms of change and provide an understanding of health workers in providing optimal services.

\section{REFERENCES}

[1] Yusuf, M., Strategi manajemen perubahan pola pikir SDM guna menghadapi persaingan era industri 4.0 industri manufaktur, Jurnal Program Studi Akuntansi, Fakultas Ekonomi, Universitas Batik Surakarta, 2017, pp. 648-664.

[2] Arijanto, A., Perkasa, D. H., Widayati, C., \& Retno, N. E., Manajemen perubahan, Halaman Moeka Publishing, 2018.

[3] RSUP Wahidin, Layanan rumah sakit dr. wahidin sudirohusodo Makassar, 2020. Retrieved from: https://www.rsupwahidin.com/Layananrujukan-rsup-wahidin-sudirohusodo. html. Accessed at 14 January 2021.

[4] Holt, D., Armenakis, A., Feild, H., \& Harris, S., Readiness for organizational change: the systematic development of a scale, The Journal of Applied Behavioral Science, 2007, 43(2), pp. 232-255.

[5] Aljohani, M. R., Change management, International Journal of Scientific \& Technology Research, 2016, 5(5), pp. 319-323.

[6] McClusky, H., Course of the adult life span, W.C. Hallenbeck (Ed.), 10-19, 1964.

[7] Hanpachern, C., The extension of theory of margin: a framework for assessing readiness for change, Unpublish Doctoral Dissertation, 1997.

[8] Madsen, S., John, C., Miller, D., \& Warren, E., The relationship between an individual's margin in life and readiness for change, Utah Valley State College Journal, 2003, pp. 759-766.

[9] Majid, N. F., Kontribusi learning organization terhadap readiness for change pada pegawai rumah sakit X kota makassar, Fakultas Kedokteran Program Studi Psikologi Universitas Hasanuddin, 2018.

[10] Saragih, E. H., Individual attributes of change readiness: a case study at Indonesia state-owned railway company, Procedia Social and Behavioral Science, 2015, (172), pp. 34-41.

[11] Kalynych, C., The application of margin in life theory in regard to attrition and remediation among emergency medicine residents, UNF Graduate Theses and Dissertations, 2010, pp. 1158.

[12] Merriam, S., \& Caffarella, R., Learning in adulthood: a comprehensive guide, Jossey-Bass Publisher, 1999. 